\title{
KARAKTERISTIK KASUS KONSUMEN DAN FAKTOR PENGHAMBAT PENDIRIAN BPSK (BADAN PENYELESAIAN SENGKETA KONSUMEN) DI WILAYAH MADURA
}

\author{
Murni, Erma Rusdiana, Rina Yulianti. Fakultas \\ Hukum Universitas Trunojoyo Madura Email: \\ abundarina@gmail.com, ermarusdiana@ \\ ymail.com, murni_msy@yahoo.co.id
}

\begin{abstract}
This empirical legal research aims to describe reality factors that caused not established BPSK (Consumer Disputes Resolution Board) in Madura area. Characteristics of Consumer Disputes in Madura used as early Informed to mapping the factors inhibited BPSK in Madura. In-depth interviews and Focus Group Discussion (FGD) was conducted to mapping of consumer cases characteristic that happened in Madura, furthermore, this research classified factors that caused not established BPSK in Madura. Results of this study mapping the structural and cultural problems is a major cause for the establishment of BPSK.
\end{abstract}

Key Words : Characteristic, Barriers, Consumer, BPSK

\begin{abstract}
Abstrak
Penelitian hukum empiris ini bertujuan untuk menggambarkan realitas faktor-faktor yang menyebabkan tidak berdirinya BPSK (Badan Penyelesaian Sengketa Konsumen) di wilayah Madura. Karakteristik sengketa konsumen di wilayah Madura dijadikan informasi awal untuk melakukan pemetaan terhadap faktor-faktor yang menghambat adanya BPSK di Madura. Interview mendalam dan Focus Group Discussion (FGD) digunakan untuk memetakan karakteristik kasus konsumen yang terjadi di Madura, selanjutnya akan di klasifikasikan faktor-faktor apa saja yang menghambat berdirinya BPSK di Madura. Hasil penelitian ini memetakan problem struktural dan budaya menjadi penyebab utama bagi pendirian BPSK.
\end{abstract}

Kata Kunci : Karakteristik, Faktor Penghambat, Konsumen, BPSK

\section{A. Pendahuluan}

Kebijakan pemerintah di wilayah Madura dalam kaitanya dengan persoalan konsumen masih bersifat preventif dan lintas sektoral oleh sebab itu dengan dibentuknya BPSK di Madura di harapkan masyarakat akan mendapatkan hak-hak nya akibat kerugian yang dilakukan oleh Pelaku usaha.

Terhadap kasus-kasus konsumen yang ada, sudah seharusnya menjadi perhatian pemerintah di wilayah Madura untuk mengidentifikasinya sehingga dapat menjadi dasar dalam menentukan kebijakan.

Konsumen di wilayah Madura juga merupakan bagian dari warga negara di Indonesia yang berhak atas perlakuan yang sama sebagai perwujudan perlindungan terhadap hak asasi manusia berdasarkan Pasal Pasal 28 D butir (1) dan pasal 28 I butir (4) UUD RI Tahun 1945.
Kebijakan terkait perlindungan konsumen pasca di undangkannya UUPK nomor 8 Tahun 1999 di wilayah Madura masih terbatas pada usaha yang bersifat preventif yaitu berupa pengawasan melalui operasi pasar oleh dinas terkait dan sosialisasi perlindungan konsumen berbentuk penyuluhan dan brosur menjadi konsumen cerdas. Model pengaturan hukum yang dapat menjadi dasar bagi pendirian BPSK di Madura adalah dengan "Peraturan Daerah" hal ini untuk memberikan kepastian hukum bagi keberadaan BPSK terutama berkaitan dengan masalah pendanaan.( Hasil penelitian hibah bersaing TA 2013-2014, dengan judul "PBSK (Badan Penyelesaian Sengketa Konsumen) Sebagai Alternatif Pemenuhan HakHak Konsumen di Madura, laporan hasil pada LPPM Universitas Trunojoyo Madura)

Perlindungan terhadap konsumen merupakan salah satu tujuan negara dalam menegakkan

Karakteristik Kasus Konsumen... 
hak asasi manusia sesuai dengan amanah UUD 1945, akan tetapi secara represif menegakkan hak konsumen melalui mekanisme di luar pengadilan yaitu dengan mendirikan BPSK (Badan Penyelesaian Sengketa Konsumen) di wilayah Madura sampai saat ini belum bisa diwujudkan. BPSK sudah seharusnya menjadi rujukan bagi konsumen yang dirugikan, karena mekanisme ini lebih cepat dan sederhana berbeda dengan mekanisme formal (pengadilan) yang dikenal lama dengan biaya mahal.

Permasalahan yang dapat di kemukakan dalam penelitian ini adalah : "Bagaimanakah karakteristik kasus konsumen dan faktor apakah yang menghambat berdirinya BPSK di wilayah Madura?".

\section{B. Metode Penelitian}

Penelitian hukum empiris merupakan jenis penelitian yang digunakan untuk mencapai tujuan dalam penelitian ini, Interview mendalam dan Focus Group Discussion (FGD) dengan pihak pemerintah daerah. masyarakat, dan lembaga swadaya masyarakat di wilayah Maura digunakan untuk memetakan karakteristik kasus konsumen yang terjadi di Madura, selanjutnya di klasifikasikan faktor-faktor apa saja yang menghambat berdirinya BPSK di Madura.

\section{Hasil Penelitian dan Pembahasan \\ 1. Karakteristik Kasus Konsumen di Wilayah} Madura

Menurut AZ. Nasution, sengketa konsumen dapat diartikan sebagai setiap barang dan/atau jasa pelaku usaha dalam hubungan hukum antara satu sama lain mengenai produk tersebut.( AZ Nasution, 2000 : 178)

Sedangkan Shidarta mengemukakan bahwa sengketa konsumen pada dasarnya merupakan sengketa berkenaan dengan pelanggaran hak-hak konsumen, yang lingkupnya mencakup segi hukum keperdataan, pidana maupun tata negara.( Shidarta, $2000:$ 135)

Menjadi konsumen cerdas harusnya dimiliki oleh semua lapisan masyarakat, menunggu operatifnya undang-undang mengenai perlindungan konsumen (UUPK) bak menunggu jatuhnya bintang. Miskinnya penegakan hukum dan perhatian pemerintah terhadap kedudukan konsumen menyebabkan masyarakat lebih permisif terhadap kasuskasus konsumen.
Sependapat dengan tulisan Fendi Setyawan, secara teoritis sengketa-sengketa konsumen dapat diselesaikan. Namun, dalam praktek dan kenyataannya tidak mudah dilakukan karena berbagai sebab. (Fendi Setyawan, 2001, : 33-47)

Undang-undang mengatur dengan tegas mengenai hak dan kewajiban baik bagi konsumen maupun produsen, tetapi sulit mengaplikasikannya.

Upaya mewujudkan perlindungan konsumen sangat tergantung pada peran dan sikap kritis konsumen sebagai pembeli barang atau jasa. Namun, faktor lain yang juga tidak kalah penting adalah sikap produsen sebagai pihak pemroduksi barang atau jasa yang seharusnya berorientasi pada kepuasan konsumen dan barang yang diproduksi memenuhi standar mutu yang telah ditetapkan. Pemerintah dalam hal ini berkaitan dengan pembuatan UndangUndang Perlindungan Konsumen, dan Departemen Perdagangan harus mengawasi produk atau jasa yang beredar di dalam perdagangan dalam negeri, yang diekspor maupun yang diimpor, serta peran dari aktivitas organisasi konsumen itu sendiri.( Euis Soliha, 1999 : 93-105)

Undang-Undang Nomor 8 Tahun 1999 tentang Perlindungan Konsumen, mengatur hak konsumen seperti yang terdapat dalam Pasal 4 UUPK, yaitu meliputi:

a. hak atas kenyamanan, keamanan, dan keselamatan dalam mengkonsumsi barang dan /atau jasa,

b. hak untuk memilih barang dan/atau jasa serta mendapatkan barang dan/atau jasa tersebut sesuai dengan nilai tukar dan kondisi serta jaminan

c. hak atas informasi yang benar, jelas dan jujur mengenai kondisi dan jaminan barang dan /atau jasa,

d. hak untuk didengar pendapat dan keluhannya atas barang dan latau jasa yang digunakan,

e. hak untuk mendapatkan advokasi, perlindungan dan upaya penyelesaian sengketa perlindungan konsumen secara patut,

f. hak untuk mendapat pembinaan dan pendidikan konsumen,

g. hak untuk diperlakukan atau dilayani secara benar dan jujur serta tidak diskriminatif,

i. hak untuk mendapatkan kompensasi, 
ganti rugi dan/atau penggantian, apabila barang dan/atau jasa yang diterima tidak sesuai dengan perjanjian atau tidak sebagaimana mestinya,

j. hak-hak yang diatur dalam ketentuan peraturan perundang-undangan lainnya.

Akan tetapi Konsumen tidak hanya dilindungi dengan haknya saja tetapi konsumen juga harus mematuhi kewajibannya sesuai dengan Pasal 5 UUPK yang meliputi:

a. membaca atau mengikuti petunjuk informasi dan prosedur pemakaian atau pemanfaatan barang dan/atau jasa, demi keamanan dan keselamatan,

b. beritikad baik dalam melakukan transaksi pembelian barang dan/atau jasa,

d. membayar sesuai dengan nilai tukar

e. mengikuti upaya penyelesaian hukum sengketa konsumen secara patut.

Wewenang Badan Penyelesaian Sengketa Konsumen dalam menyelesaikan sengketa konsumen menurut Pasal 52 Undang-undang Perlindungan Konsumen jo Kepmenperindag Nomor 350/MPP/Kep/12/2001 tentang Pelaksanaan Tugas dan Wewenang Badan Penyelesaian Sengketa Konsumen yaitu :

a. Melaksanakan penanganan dan penyelesaian sengketa konsumen, dengan cara mediasi atau arbitrase atau koalisi;

b. Memberikan konsultasi perlindungan konsumen;

c. Melakukan pengawasan terhadap pencantuman klausula baku;

d. Melaporkan kepada penyidik umum apabila terjadi pelanggaran ketentuan dalam undangundang lain;

e. Menerima pengaduan baik tertulis maupun tidak tertulis, dari konsumen tentang terjadinya pelanggaran terhadap perlindungan konsumen;

f. Melakukan penelitian dan pemeriksaan sengketa perlindungan konsumen;

g. Memanggil pelaku usaha yang diduga telah melakukan pelanggaran terhadap perlindungan konsumen;

h. Memanggil dan menghadirkan saksi, saksi ahli dan/atau setiap orang yang dianggap mengetahui pelanggaran terhadap undangundang ini;

i. Meminta bantuan penyidik untuk menghadirkan pelaku usaha, saksi, saksi ahli atau setiap orang bagaimana dimaksud pada huruf $g$ dan huruf $h$, yang tidak bersedia memenuhi panggilan badan penyelesaian sengketa konsumen;

j. Mendapatkan, meneliti dan/atau menilai surat, dokumen atau alat bukti lain guna penyelidikan dan/atau pemeriksaan;

k. Memutuskan dan menetapkan ada atau tidak adanya kerugian di pihak konsumen;

I. Memberitahukan putusan kepada pelaku usaha yang melakukan pelanggaran terhadap perlindungan konsumen;

m. Menjatuhkan sanksi administratif kepada pelaku usaha yang melanggar ketentuan undang-undang ini.

Berdasarkan tugas dan wewenang tersebut, maka dengan demikian terdapat 2 fungsi strategis dari BPSK yaitu :

a. BPSK berfungsi sebagai instrument hukum penyelesaian sengketa di luar pengadilan yaitu melalui konsiliasi, mediasi, arbitrase;

b. Melakukan pengawasan terhadap pencantuman klausula baku oleh pelaku usaha. Termasuk disini klausula baku di bidang kelistrikan, telekomunikasi, bank, perusahaan pembiayaan. Salah satu fungsi strategis ini adalah menciptakan keseimbangan kepentingan kepentingan pelaku usaha dan konsumen.

Meskipun demikian urusan perlindungan konsumen tidaklah semudah yang tertulis dalam undang-undang, berbagai kasus seringkali tidak mendapat perhatian yang serius oleh pemerintah. Untuk itu tim peneliti mencoba menginventarisir karakter kasus konsumen di wilayah Madura seperti tersebut di bawah ini : 
Tabel 1. Karakteristik Kasus Konsumen di Wilayah Madura

\begin{tabular}{|c|c|c|}
\hline JENIS KASUS & MODUS & PELAKU USAHA \\
\hline $\begin{array}{l}\text { - Korban Produk Properti } \\
\text { - Korban Produk Mamin } \\
\text { (Makanan dan Minuman) } \\
\text { - Korban Produk Jasa Haji } \\
\text { - Korban pasar modern }\end{array}$ & 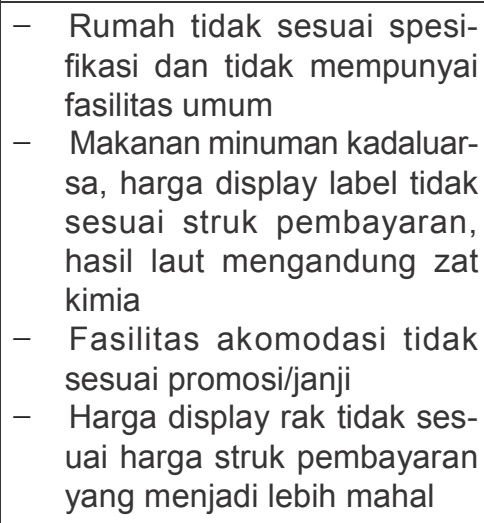 & Swasta \\
\hline $\begin{array}{l}\text { - Korban Pelayanan Kese- } \\
\text { hatan } \\
\text { - Korban Pelayanan PLN } \\
\text { - Korban Pelayanan PDAM } \\
\text { - Korban Pelayanan Gas } \\
\text { - Kesulitan Pupuk }\end{array}$ & 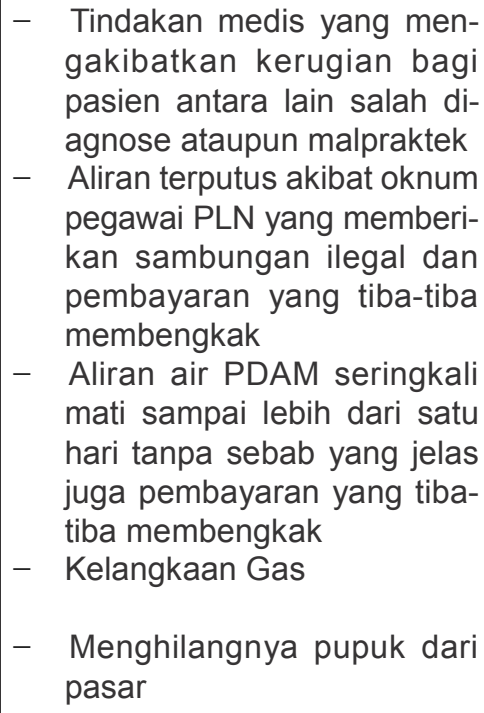 & $\begin{array}{l}\text { Milik Pemerintah } \\
\text { (BUMD/BUMN) }\end{array}$ \\
\hline
\end{tabular}

Sumber : Hasil wawancara dengan Bapak Jimhur Saros pimpinan YLKI wilayah Madura dan berbagai sumber dari penelusuran lapangan.

Berdasarkan penelusuran tim peneliti terkait kasus konsumen, di empat kabupaten di wilayah Madura mempunyai karakter yang sama. Kasuskasus yang bersumber dari pelaku usaha swasta atau produsen swasta yaitu korban konsumen perumahan/property dengan modus rumah tidak sesuai spesifikasi dan tidak adanya fasilitas umum, produk makanan minuman kadaluarsa, pelayanan wisata religi atau umroh tidak sesuai promo dan di timbunnya gas/LPG oleh distributor.
Hadirnya pasar modern terbesar di kota Kabupaten Bangkalan yang selama ini hanya ada di Surabaya pelayanannya tidak sebaik yang di bayangkan. Sumber kami menyebutkan dengan gamblang, sudah dua kali berbelanja di pasar modern terbesar tersebut mengalami kejadian yang merugikan. Pertama pembayaran untuk pembelian sejumlah satu barang tercatat dalam struk pembayaran lebih dari satu, kedua, display harga pada rak barang yang di jual harganya 
menjadi lebih mahal pada struk pembayaran. Kejadian ini tentunya sangat merugikan konsumen, akan tetapi kembali lagi masyarakat sebagai konsumen tidak mempunyai wadah/saluran.

Menurut Bapak Jimhur Saros Ketua YLKI Madura, kasus lainnya terjadi di kecamatan Socah, Kabupaten Bangkalan, masyarakat mengalami kerugian akibat ulah oknum PLN yang tidak bertanggung jawab. Awalnya warga yang belum mempunyai sambungan PLN mengusulkan untuk pasang baru, ternyata setelah berjalan beberapa bulan, aliran listrik mereka diputus oleh PLN, usut punya usut ternyata listrik yang dijanjikan pasang baru oleh oknum tersebut hanya dilakukan loss stroum atau biasanya kita kenal sebagai aliran tanpa melalui meter, selama ini warga membayar pada oknum petugas. Akhirnya setelah ketahuan pihak PLN aliran listrik warga secara sepihak diputus. Warga yang selama ini tidak mengetahui bahwa aliran mereka illegal akhirnya harus menanggung kerugian.(Wawancara tertutup dengan Bapak Jimhur Saros, pimpinan YLKI wilayah Madura pada 8 Juni 2014)

\section{Faktor Penghambat Berdirinya BPSK di Madura}

Tujuan pembangunan nasional Indonesia adalah mewujudkan masyarakat adil dan makmur yang merata dalam era demokrasi ekonomi berdasarkan Pancasila dan UndangUndang Dasar Negara Republik Indonesia Tahun 1945. Pembangunan perekonomian nasional pada era globalisasi harus dapat mendukung tumbuhnya dunia usaha sehingga mampu menghasilkan bermacammacam barang dan/atau jasa yang dapat meningkatkan kesejahteraan masyarakat banyak, sekaligus mendapatkan kepastian atas barang dan atau jasa yang diperoleh dari perdagangan tanpa mengakibatkan kerugian kepada konsumen.

Indonesia disebut sebagai negara hukum, sebagaimana yang tercantum dalam UUD 1945 pasal 1 ayat (3), yang berdiri di atas hukum, berkewajiban untuk melindungi hak-hak warga negaranya, dan setiap warga negara berhak mendapatkan perlindungan hukum, dalam rangka meningkatkan harkat dan martabatnya. Konsumen yang merupakan asset dan pelaku pembangunan nasional dan turut serta dalam kegiatan ekonomi, sehingga wajib dilindungi oleh hukum. Negara Hukum merupakan institusi untuk mewujudkan keadilan dalam masyarakat.

Sejak Undang-Undang Perlindungan Konsume yang telah di undangkan sejak
20 April 1999, ternyata implementasinya masih jalan di tempat. UU yang diharapkan mampu menjadi senjata bagi konsumen ini belum mendapat ruang yang cukup untuk segera diberlakukan. Berbagai kendala masih menghadang dalam upaya implementasinya. Kendala utamanya bukanlah teknis, tetapi lebih pada kendala politis. Saat ini tampaknya pemerintah memiliki prioritas politik tersendiri dan tidak cukup energi untuk serius menegakkan hak konsumen dengan mengimplementasikan UU PK ini. Secara lebih rinci dapat disebutkan bahwa kendala yang dihadapi paling tidak ada tiga, yaitu (Harmono, di akses pada 15 Juli 2013):

Pertama, belum segera berdirinya Badan Penyelesaian Sengketa Konsumen (BPSK) dibererapa kota atau Kabupaten seperti di Karisidenan Banyumas. Badan inilah sebenarnya yang menjadi ujung tombak secara institusional bagi pelaksanaan perlindungan konsumen sekaligus penyelesaian setiap sengketa yang terjadi antara konsumen dengan pelaku usaha. Pemerintah adalah penanggung jawab atas terbentuknya badan ini. BPSK dibentuk dan berkedudukan di Daerah Tingkat II seperti di Purbalingga yang sudah menjamur beberapa LPKSM pun belum ada lembaga penyelesaian sengketa tersebut padahal sudah banyak aduan, di Intansi Dinas perdagangan dan perindustrian Kabupaten hanya ada Kepala Seksi Bidang Perlindungan Konsumen. Kedua, masih rendahnya kesadaran konsumen dalam memperhatikan dan menegakkan hak-haknya. Konsumen sering kali tidak memperhatikan perjanjian dan tidak peduli atas informasi sejelas-jelasnya tentang isi perjanjian, mereka seringkali cuma membubuhkan tanda tangan pada perjanjian kredit ataupun perjanjian lainnya yang sudah di konsep pelaku usaha sehingga sepihak. Hal ini secara langsung maupun tidak akan mempengaruhi keseriusan pemerintah dan semua kalangan terkait dalam menjalankan UU PK. Sudah menjadi rahasia umum bahwa tekanan dan dorongan dari masyarakat bawah merupakan pemicu ampuh bagi pemerintah untuk segera merespon sebuah kebijakan. Dari kedua faktor yang menghambat terimplementasinya UU Perlindungan Konsumen tersebut, terlihat bahwa sebab utamanya adalah masalah politik yaitu ketidak seriusan pemerintah untuk menjalankannya. Ketiga, adalah masalah kultur. 
Aristoteles menyatakan bahwa "keadilan adalah suatu kebijakan politik yang aturanaturannya menjadi dasar dari peraturan negara dan aturan-aturan, ini merupakan ukuran tentang hak". Orang harus mengendalikan diri dalam mencari keuntungan bagi diri sendiri dengan merebut apa yang merupakan kepunyaan orang lain, atau menolak apa yang seharusnya diberikan kepada orang lain.( Muhammad.S.T, Armia, 2008 : 63)

Melindungi atau memberdayakan konsumen menurut Abdul R Saliman diperlukan seperangkat aturan hukum, oleh karena itu diperlukan campur tangan Negara melalui penetapan sistem perlindungan hukum terhadap konsumen.( Abdul R, Saliman dkk, 2006 : 219)

Berdirinya YLKI (Yayasan Lembaga Konsumen Indonesia) perwakilan Madura hanya memberi setitik harapan bagi konsumen, menurut Bapak Jimhur Saros pimpinan YLKI Madura di Bangkalan, terbatasnya dana untuk operasional serta sosialisasi dan minimnya perhatian Pemerintah di daerah menjadikan YLKI menjadi tidak optimal. Akan tetapi lembaga ini menurut Bapak Jimhur secara swadaya tetap ingin dan eksis dalam mengawal hak-hak konsumen. Apalagi menurut beliau pengaduan dari masyarakat untuk saat ini terbanyak dari maraknya nelayan tradisional atau tengkulak yang menggunakan bahan kimia untuk mengawetkan hasil tangkapannya. Harapan beliau pemerintah bisa andil secara serius melindungi hak-hak konsumen. (Wawancara tertutup pada YLKI wilayah Madura diwakili oleh Bapak Jimhur Saros pada 27 Juni 2014)

Hal ini seharusnya menjadi perhatian serius pihak-pihak yang mempunyai otoritas terutama penegak hukum, karena menyangkut kesehatan masyarakat kebanyakan.

Wilayah Madura juga belum didukung adanya perangkat layanan yang menunjang bekerjanya BPSK, seperti BPOM, balai pengujian, UTTP (Ukur Takar Timbang dan Perlengkapannya), serta layanan konsumen lainnya ditingkat kabupaten.(Hasil FGD dengan perwakilan dinas terkait sewilayah Madura, Mei-Juli 2014)

Memperhatikan peluang dan hambatan yang ada terhadap pendirian BPSK di wilayah Madura dapat di gambarkan dalam tabel berikut ini :

Tabel 2. Hambatan dan Peluang Pengaturan Hukum BPSK di Madura

\begin{tabular}{|c|l|l|}
\hline NO & \multicolumn{1}{|c|}{ HAMBATAN } & \multicolumn{1}{|c|}{ PELUANG } \\
\hline 1 & $\begin{array}{l}\text { Problem Struktural : } \\
\text { Baik Pemerintah maupun masyara- } \\
\text { kat menyatakan bahwa Peraturan } \\
\text { Daerah yang mengatur tentang } \\
\text { pembentukan BPSK belum ada, } \\
\text { persoalan pendanaan juga menjadi } \\
\text { pertimbangan pemerintah. }\end{array}$ & program legislasi daerah di wilayah Madura. \\
\hline 2 & $\begin{array}{l}\text { Problem Budaya: } \\
\text { Alasan permisif oleh masyarakat dan } \\
\text { penegak hukum terhadap pelangga- } \\
\text { ran yang dilakukan oleh pelaku usaha } \\
\text { menjadi hambatan bagi penegakan } \\
\text { hukumnya. Hal ini menjadikan BPSK } \\
\text { tidak lagi sebagai wadah/lembaga } \\
\text { yang bisa menjadi penting bagi per- }\end{array}$ & isasi ini melalui berbagai saluran media dan \\
lindungan konsumen. & \\
\hline
\end{tabular}

Sumber : di olah dan dikaji peneliti berdasarkan hasil temuan di lapangan 
Tabel di atas menyebutkan bahwa problem struktural menjadi hambatan utama tidak terwujudnya pendirian BPSK di Madura. Perwakilan pemerintah terkait hal ini menjelaskan bahwa tanpa adanya peraturan daerah yang menjadi payung, mustahil bagi mereka untuk melangkah lebih jauh, terlebih lagi bila berkaitan dengan hal penggunaan anggaran.

\section{Simpulan}

Karakteristik kasus konsumen di wilayah Madura lebih bersifat kasus individual meskipun sebenarnya dari segi korban bisa bersifat kelompok bila dialami secara bersamaan, akan tetapi keluhan-keluhan dari korban yang ada lebih bersifat pribadi. Kasus yang terjadi antara lain korban sebagai konsumen makanan dan minuman kadaluarsa, konsumen property, konsumen jasa wisata religi, konsumen PDAM, konsumen PLN, konsumen hasil laut mengandung zat kimia yang membahayakan kesehatan, konsumen pupuk, konsumen jasa medis, konsumen pasar modern. Sedangkan dari segi Pelaku Usaha, kerugian dilakukan baik oleh Pelaku Usaha yang notabene adalah milik pemerintah dan juga pihak swasta.

Konsumen di wilayah Madura juga merupakan bagian dari warga negara di Indonesia yang berhak atas perlakuan yang sama sebagai perwujudan perlindungan terhadap hak asasi manusia berdasarkan Pasal Pasal 28 D butir (1) dan pasal 28 I butir (4) UUD RI Tahun 1945. Peraturan Daerah diperlukan untuk memberikan jaminan kepastian hukum bagi pendirian BPSK di wilayah Madura, tidak adanya payung hukum ini menjadi problem bagi semua instansi teknis terkait untuk mengusulkan berdirinya BPSK. Sikap permisif terhadap pelaku usaha oleh masyarakat juga menjadi problem budaya yang menghambat adanya BPSK di Madura.

\section{E. Saran}

Konstruksi yuridis peraturan daerah tentang perlindungan konsumen serta penyediaan lembaga-lembaga layanan yang mendukung berdirinya BPSK harusnya bisa secepatnya di respon oleh pemerintah di wilayah Madura mengingat masyarakat sebagai konsumen di Madura juga berhak mendapat perlakuan dan perlindungan yang sama di hadapan hukum.

\section{F. Persantunan}

Ucapan terimakasih pada Kementerian Ristek dan Dikti melalui Dit.Litabmas Dirjen DIKTI yang telah mendanai penelitian ini melalui program Penelitian Hibah Bersaing BOPTN pada Universitas Trunojoyo Madura Tahun Anggaran 2013-2014.

\section{Daftar Pustaka}

Abdul R, Saliman dkk. 2006. Hukum Bisnis Untuk Perusahaan. Jakarta: Kencana.

Nasution, AZ. 2000. Konsumen dan Hukum Jakarta: Pustaka Sinar Harapan.

Shidarta, 2000. Hukum Perlindungan Konsumen. Jakarta : Grasindo.

Muhammad.S.T, Armia. 2008. Perkembangan Pemikiran Teori Ilmu Hukum. Jakarta: Pradnya Paramita.

Harmono. Perlindungan Konsumen Jalan Di Tempat. Banjarnegara: LPKSM.

\section{Peraturan Perundang-undangan:}

Undang-Undang Dasar Negara Republik Indonesia Tahun 1945

Undang-Undang Nomor 8 Tahun 1999 tentang Perlindungan Konsumen

Keputusan Menteri Perindustrian dan Perdagangan Nomor 301/MPP/Kep/10/2001 tentang Pengangkatan dan Pemberhentian Anggota dan Sekretariat Badan Penyelesaian Sengketa Konsumen

Surat Keputusan Menteri Perindustrian dan Perdagangan Nomor. 350/MPP/Kep/12/2001 tentang Pelaksanaan Tugas dan Wewenang Badan Penyelesaian Sengketa Konsumen

Keputusan Menteri Perindustraian dan Perdagangan Nomor 419/MPP/Kep/4/2001 tentang Pembentukan Tim Penyeleksi Penetapan Anggota Badan Penyelesaian Sengketa Konsumen

\section{Jurnal:}

Ari Purwadi,. 2001. “Model penyelesaian sengketa konsumen di Indonesia”, Jurnal Yustika, Media Hukum dan Keadilan, Fakultas Hukum Universitas Surabaya., Vol: 4 No : 2 
Fendi Setyawan, 2001, "Upaya Hukum dalam Penyelesaian Sengketa Konsumen: Suatu Tinjauan terhadap UU No. 8 Tahun 1999 tentang Perlindungan". Konsumen, Jurnal Hukum dan masyarakat Fakultas : Hukum,Universitas Jember. Vol : 2, No :1

Euis Soliha, 1999, "Peranan konsumen, produsen dan pemerintah dalam mewujudkan perlindungan konsumen", Jurnal Gema Stikubank,Sekolah Tinggi Ilmu EkonomiStikubank Semarang, Vol : 31, No: 5

Bernadetta T. Wulandari, 2006, "Badan Penyelesaian Sengketa Konsumen (BPSK) Sebagai Alternatif Upaya Penegakan Hak Konsumen di Indonesia", Jurnal Hukum Gloria Juris, Fakultas Hukum Universitas Katolik Atma Jaya Jakarta., Volume 6, No. 2.

\section{Internet:}

http://binakonsumenmerdeka.blogspot.com/, di akses pada 15 Juli 2013 